\title{
Accumulation variation in eastern Kemp Land, Antarctica
}

\author{
IAN D. GOODWIN, \\ School of Earth Sciences, University of Melboume, Parkville, Victoria 3052, Australia \\ Martix Higham, ian Allison, \\ Antartic Cooperative Research Centre, Box 252C, Hobart, Tasmania 7001, Australia and Australian Antarctic Division \\ REN JAIWEN \\ Lanzhou Institute of Glaciology and Geocryology, Chinese Academy of Sciences, Lanzhou 730000, China
}

\begin{abstract}
The spatial pattern of accumulation rate for eastern Kemp Land in the elevation range $1850-2700 \mathrm{~m}$ is presented together with observations of the physical parameters of snow temperature, average microwave emissivity $19 \mathrm{GHz}, \mathrm{H}$ polarization), distribution of depth hoar and firn-crystal diameter. The broad accumulation pattern in the region was found to be significantly low when compared to other coastal areas of East Antarctica such as Wilkes Land. The low accumulation regime is attributed to low atmospheric moisture transport and low penetration of synoptic cyclonic systems on to the coastal slopes. In the absence of high coastal precipitation, the accumulation rate is determined predominantly by surface snowredistribution processes. Attempts to determine accumulation-rate time series using visible layer, $\delta^{18} \mathrm{O}$ isotope and electrical conductivity stratigraphies were unsuccessful due to the relatively low coastal accumulation rates (less than $280 \mathrm{~kg} \mathrm{~m}^{-2} \mathrm{a}^{-1}$ ) and the complex modification of precipitation by redistribution processes. $\delta^{18} \mathrm{O}$ variations of seemingly cyclic nature observed throughout the cores were interpreted as a product of the snow-dune building and erosion processes, together with general redistribution of snows by the surface wind field, under the influence of mesoscale topographic roughness.
\end{abstract}

\section{INTRODUCTION}

Eastern Kemp Land is located on the western slopes of the Lambert Glacier basin (Fig. 1). The continental-wide accumulation-rate distributions published by Drewry and Morris (1992) and Giovinetto and Bull (1987) indicate that coastal accumulation rates reach their lowest values in the Kemp Land region, between $50^{\circ}$ and $60^{\circ} \mathrm{E}$. This region of low coastal accumulation rates contrasts with the higher coastal accumulation-rate pattern in Wilkes Land investigated earlier (Goodwin, 1990, 1991).

As part of the ANARE Lambert Amery Regional Glaciology Experiment (LARGE), spatial accumulationratc measurements in Kemp Land were made on canes placed every $2 \mathrm{~km}$ along the main oversnow traverse routc between about $55^{\circ}$ and $61^{\circ} \mathrm{E}$ for the period $1989-92$ (Fig. 1). Previous measurements were made along approximately $68^{\circ} 39^{\prime} \mathrm{S}$ for the period 1975-78 (Morgan and Jacka, 1981). The elevation range of the accumulation measurements is between 1850 and $2700 \mathrm{~m}$. Shallow firn-core drilling to depths of 15-27 m was carried out at seven locations in an attempt to determine accumulationrate time scries for the region. Threc of the drilling sites (LGB00, MGA and E065) were located along the line reported by Morgan and Jacka (1981) and are discussed in this paper. Accumulation-ratc time series werc also measured between 1983 and 1992 at a grid of 25 canes spaced at $50 \mathrm{~m}$ intervals at LGB00. The spatial and temporal accumulation-rate measurements and distributions are discussed togcther with the dominant surface processes observed throughout the region.

\section{SPATIAL ACGUMULATION DISTRIBUTION}

The $10 \mathrm{~km}$ mean accumulation-rate measurements fivecanc averages) along the traverse route are shown in Figure 2 for the epoch 1989-92 (although the southernmost $120 \mathrm{~km}$ are for $1989-90$ only). The accumulation and elevation profiles are plotted against continentality (distance from the coast and moisture source), for comparison, the $10 \mathrm{~km}$ mean accumulation-rate measurement for $110^{\circ} \mathrm{E}$ is also shown in Figurc 2 for the same elevation range. The $110^{\circ} \mathrm{F}$ region is representative of 1 ilkes Land and the coastal slopes of much of East Antarctica.

For the Kemp Land line, the accumulation-rate pattern displays almost no systematic variation from a mean of approximately $150 \mathrm{~kg} \mathrm{~m}^{-2} \mathrm{a}^{-1}$ with either clevation or continentality. Variability along this line is high, with a range of between 80 and $200 \mathrm{~kg} \mathrm{~m}^{-2} \mathrm{a}^{-1}$. In contrast, the Wilkes Land profile displays a typically strong gradient of decreasing accumulation with both increasing clcvation and contincntality. The accumulation in Wilkes Land is approximately twice that of 


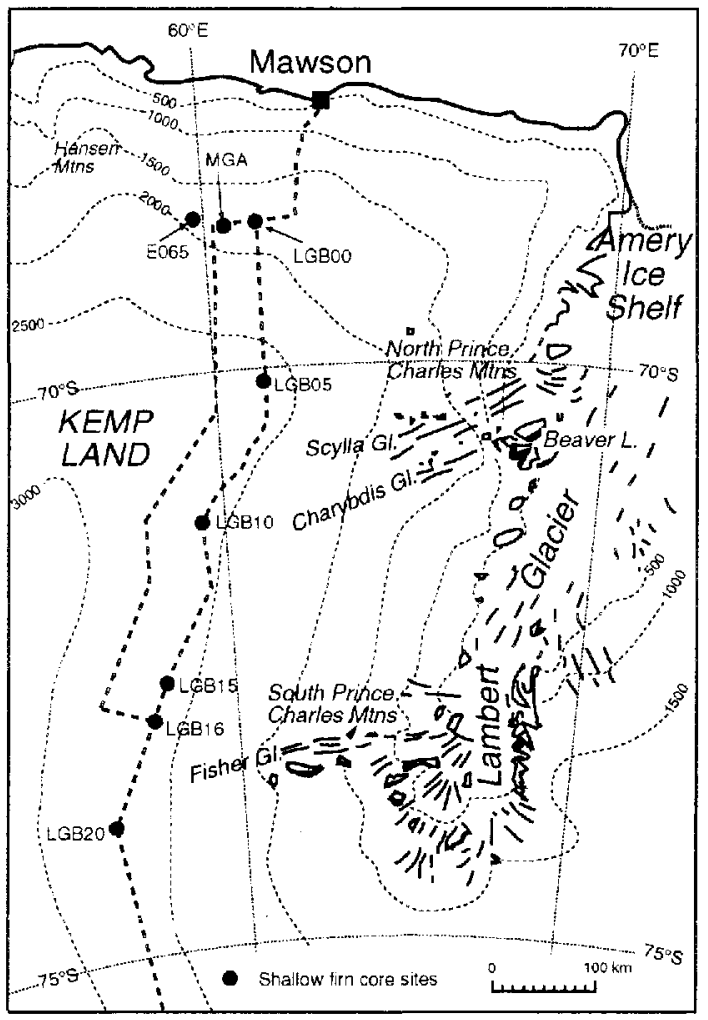

Fig. I. Location map showing trazerse routes and sites of shallowe firn cores drilled in 1990-91 and 1992-93. Elecation contours are derived from Drewry (1983) and A. IRE traverses.

Kemp Iand at $1850 \mathrm{~m}$ elevation and approximately the same at $2600 \mathrm{~m}$.

The difference in accumulation rates below $2600 \mathrm{~m}$ for the two regions, and the equivalence above $2600 \mathrm{~m}$, is interpreted as being due to the different snow-precipitation mechanisms experienced by the coastal slopes and the interior plateau. Below $2600 \mathrm{~m}$, on the coastal slope of Wilkes Land, the precipitation is controlled by incursions of maritime air masses. However, Bromwich 1988) showed from modelling that the atmospheric moisture transport in the western Lambert Glacier basin is anomalously low because net air movement is northward, rather than southward or poleward, as for the remainder of East Antarctica. Strong penetration of maritime cyclones across the coastal slopes in Kemp $\mathrm{I}$ and is not apparent. In addition, Giovinetto and others (1992) indicated that the coastal slopes in the Kemp Land region are dominated by a divergent surface-wind field, which would result in the deposition of redistributcd surface snow over a wider area down-wind. Without the strong penetration of maritime cyclones across the coastal slopes, the precipitation rate is significantly lower, and net accumulation at a site is largely controlled by interaction between the surfacewind field and snow-rcdistribution processes. The significant mesoscale topographic roughness in Kemp Land therefore results in the local accumulation-rate pattern being spatially highly variable on the scale of $10 \mathrm{~km}$.

Surface observations and shallow firn drilling $2-5 \mathrm{~m}$ deep) in eastern Kemp Land showed extensive depthhoar formation at elevations of $1850-2700 \mathrm{~m}$ on the coastal slopes and on the plateau. 'This is in strong contrast to other areas on the East Antarctic coastal slopes in Wilkcs Land where cxtensive depth hoar is restricted to the higher elevations of the polar plateau above $2500 \mathrm{~m}$ elevation.

The extreme spatial variability of snow accumulation in Kemp Land can best be illustrated along 68 $39^{\prime} \mathrm{S}$, at an elevation of $1850 \mathrm{~m}$, where sites of extensive depth hoar with very low accumulation rates (less than $20 \mathrm{~kg}$ $\mathrm{m}^{2} \mathrm{a}^{1}$ from the 197578 cane measurements) exist within $10 \mathrm{~km}$ of MGA which has an average accumulation rate of $280 \mathrm{~kg} \mathrm{~m}^{2} \mathrm{a}^{1}$.

\section{RELATIONSHIP BETWEEN AGGUMULATION AND PASSIVE MICROWAVE EMISSIVITY}

The emissivity of dry polar firn at microwave frequencies has typical values in the range $0.65-0.9$. Microwave radiation emanating from snow originates from depths of

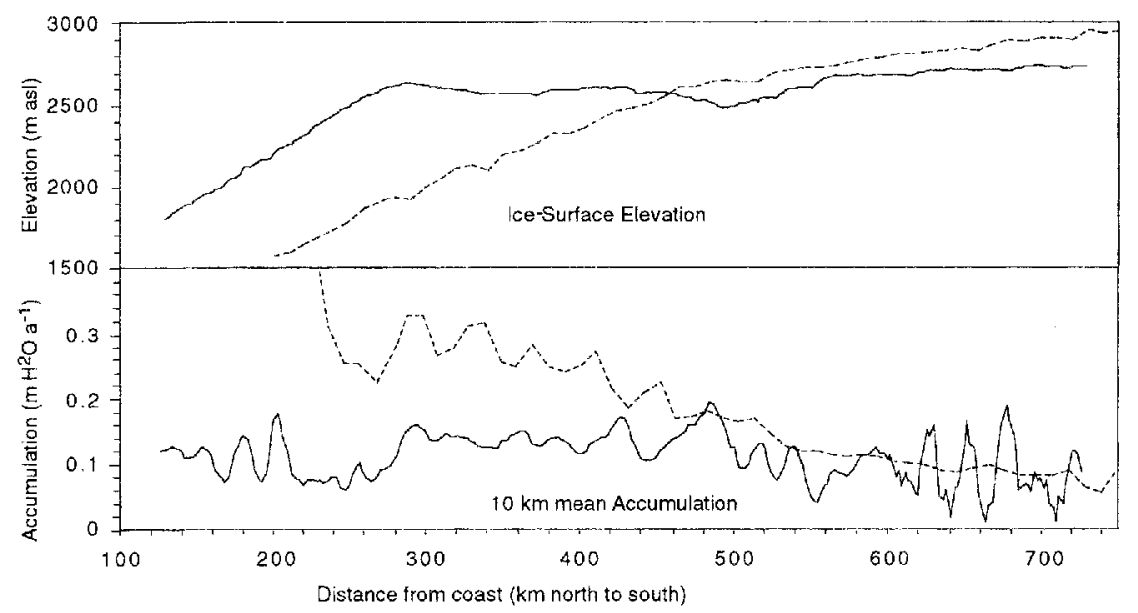

Fïg. 2. Comparison of accumulation (10 km means) and elevation profiles for eastern Kemp Land, $60^{\circ} \mathrm{E}$ (solid lines) and Wilkes Land, $110^{\circ} \mathrm{E}$ (dashed lines). For eastern Kemp Land, the accumulation measurements from 130 to $610 \mathrm{~km}$ are for a 3 year period but only for a 1 year period from 610 to $730 \mathrm{~km}$. Accumulation measurements in Wilkes Land are for a 6 year period. 
up to several metres below the surface, and the relatively low emissivity is predominantly a result of volumescattering of the radiation from grains within the snowpack (Zwally, 1977). Larger grains act as more effective volume-scattcrers and hence result in a lower emissivity. In snow undergoing destructive metamorphism, grain-size and density increase with lime, and the grain-size at any depth is dependent on both the temperature which determines the rate of metamorphism) and the accumulation rate (which determines the age of the snow at that depth). For horizontally polarized microwave radiation, a secondary contribution to reduced emissivity comes from downward reflection at the snow-air, or an internal, interface which further -decreases outgoing energy. This reflection is related to small-scalc surface roughness at the centimetre scale and/ or to the density gradient at the interface (Remy and Minster, 1991). Shuman and others (1993) have shown how formation of surface hoar over an ice shect can result in a diffuse zone of gradually decreasing density near the surface, with reduced reflection and increased emissivity.

This dependence of microwave emissivity on the physical properties of the snow has been used to derive large-scalc cstimates of the accumulation-rate distribution over Antarctica from satellite passive-microwave data (e.g. Rotman and others, 1982; Fily and Benoist, 1991). In the region covered by the Lambert Glacier basin traverse, microwave brightness temperature contours as measurcd by the Nimbus 5 Electronically Scanning Microwave Radiometer (ESMR) are almost orthogonal to elevation contours and must reflect gradients in physical properties other than temperature. Zwally (1977) defined mean emissivity as the ratio of the annual average brightness temperature to the observed mean surface temperature. This has been estimated from annual mean ESMR data for 1976 $(19 \mathrm{GHz}(1.55 \mathrm{~cm})$, horizontal polarization) and from measured $10 \mathrm{~m}$ firn tempcratures, which approximate the annual mean surface temperature. Figure 3 shows the mean cmissivity and other surface snow properties along the Iambert Glacier basin traverse route (from LGBO0 to LGB20 in Figure 1). The values of density, $\delta^{18} \mathrm{O}$, crystal diameter (measured with a scale magnifying lens) and number of ice crusts per metre are derived from the mean over the top $2 \mathrm{~m}$ of cores taken every $30 \mathrm{~km}$.

On the broad scale, there is a clear correlation between mean microwave emissivity and accumulation rate over the entire $600 \mathrm{~km}$ route. Up 10 about $520 \mathrm{~km}$ inland there is also an inverse correlation between emissivity and crystal diameter. The larger grain-sizes are associated with more numerous ice crusts and wind crusts which are produced from wind cxposure during an hiatus in accumulation. The minimum in emissivity occurs around the $250 \mathrm{~km}$ mark (LGB04, LGB05) where accumulation rates are very low and depth hoar is present, with crystals greater than $1.5 \mathrm{~mm}$ in size (compared to near-surface firn-crystal diameters of about $0.71 .0 \mathrm{~mm}$ ). North of this, on the coastal slope, accumulation rate, emissivity and crystal size all show strong and parallel gradients, despite high spatial variability in accumulation rates over short distances. The platcau between 300 and $520 \mathrm{~km}$ is marked by an

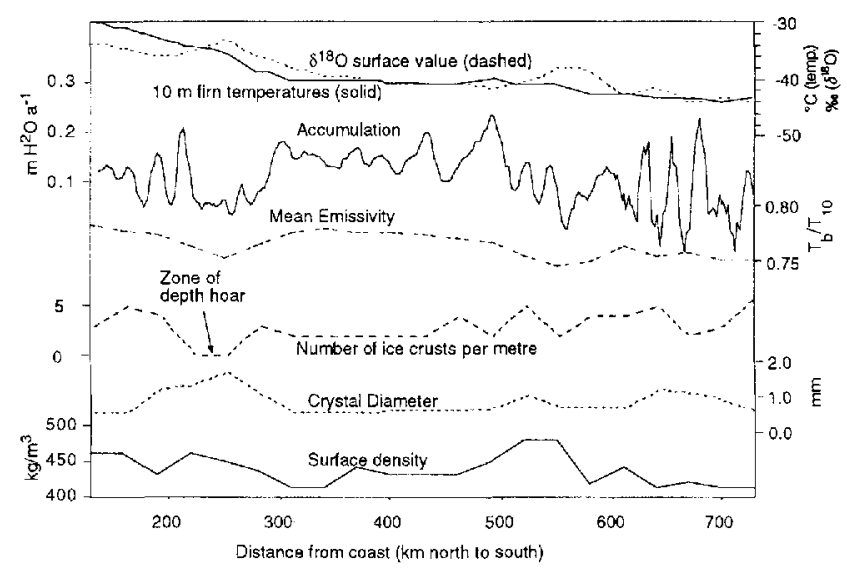

Fig. 3. Profiles of $10 \mathrm{~m}$ firn temperalure, average $\delta^{18} \mathrm{O}$, average accumulation, mean microwave emissivity (19 H) and snow properties along the traverse route between $L G B O O$ and LGB2O (Fig. 1.). Accumulation is showen as $10 \mathrm{~km}$ running means. Microwave emissivity (after Zwally, 1977) is derized from annual average ESMR brightness temperatures for 1976 and the measured $10 \mathrm{~m}$ firn temperalures. Ice cores were sampled and fim lemperatures were measured every $30 \mathrm{~km}$; the $\delta^{18} \mathrm{O}$, snow: density, crystal diameler and number of ice crusts are averages over the top $2 \mathrm{~m}$.

overall higher and more consistent accumulation regime over short distances, less surface roughness and a slightly smaller crystal diameter; variations in accumulation rate over this zone arc well represcnted in the emissivity. The lower accumulation zone at $500-600 \mathrm{~km}$ inland (approximately $100 \mathrm{~kg} \mathrm{~m}^{-2} \mathrm{a}^{-1}$ ) shows as a minimum in emissivity but the crystals remain small. The reduced emissivity in this region may be partly a result of more ice crusts in the firn resulting in greater internal reflection of the upwelling radiation. Further south than $610 \mathrm{~km}$ the accumulation rates represent only 1 year, rather than the 3 year average elsewhere, and corrclations are less clear.

Microwave brightness temperatures along the western offset route (Fig. 1) are approximately the same or slightly higher than those at an equivalent distance from the coast on the main line. This is despite the fact that the offset elevations are typically $150-$ $200 \mathrm{~m}$ higher. Meas-ured accumulation rates are not yet available for this line and it is unclear whether the implied higher emissivity is due to considerably higher accumulation rates along the offset route or to some other effect such as increased surface roughness or lower annual average surface density. Average surface densities for the top $2 \mathrm{~m}$ along the offset ranged between 382 and $434 \mathrm{~kg} \mathrm{~m}^{-3}$, with a mean of $398 \mathrm{~kg} \mathrm{~m}^{-3}$. These were significantly lower than on the main line where the range was $409471 \mathrm{~kg} \mathrm{~m}^{3}$ and the mean was $438 \mathrm{~kg} \mathrm{~m}^{-3}$. However, shallow-corc measurements show there was a tendency for more depth hoar (lower emissivity) to be present on the southern part of the offset line than on the main line. The anomalous gradient in ESMR brightness temperatures in fact extends further westward to the ice divide, which is at over $3000 \mathrm{~m}$ clcvation. 


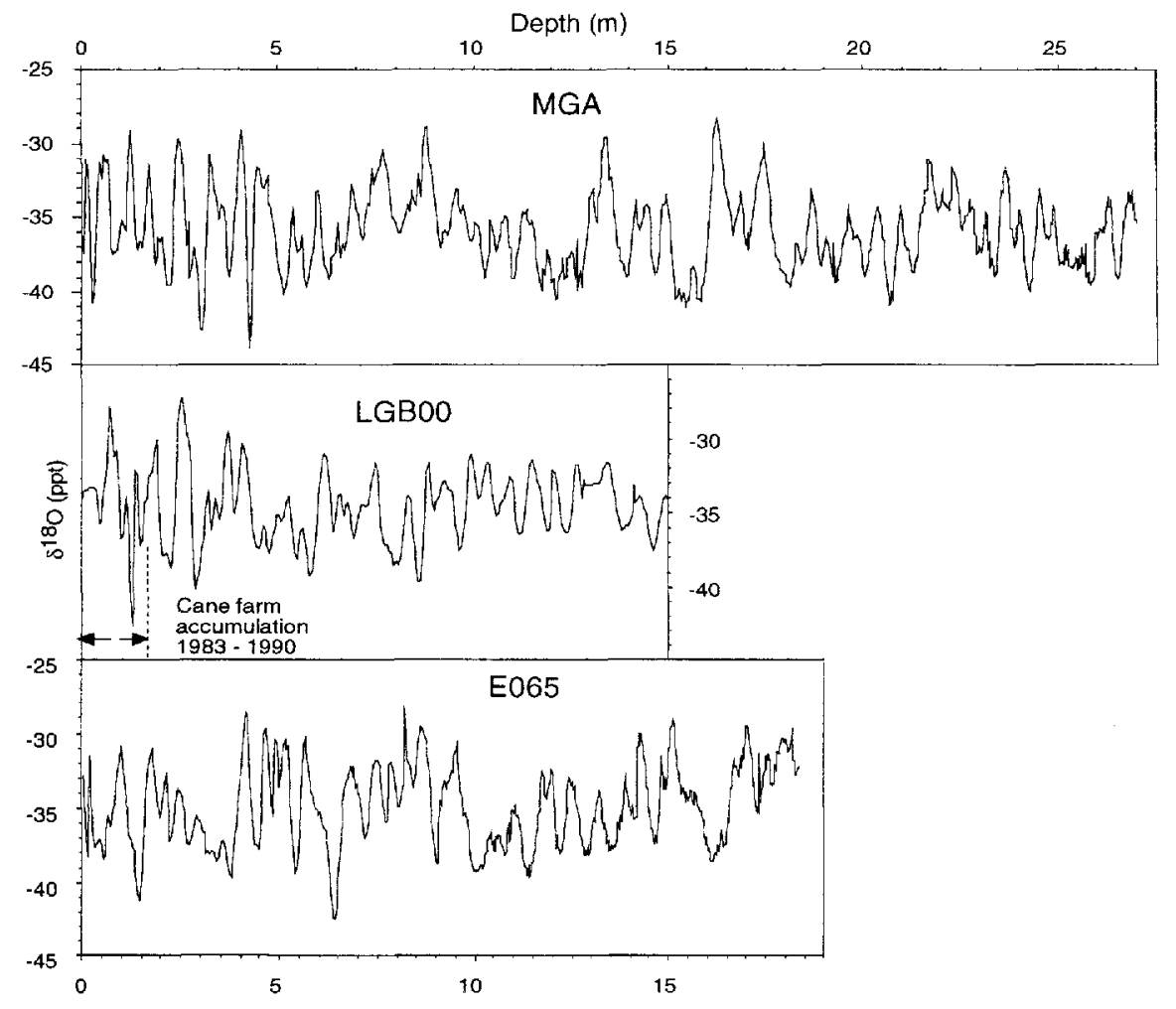

Fig. 4. $\delta^{18} \mathrm{O}$ profiles from three shallow cores situated within $50 \mathrm{~km}$ of each other at $68^{\circ} 39^{\prime} \mathrm{S}$. Cores were collected in November 1992 (MGA), February 1991 (LGB00) and February 1993 (E065). Cane measurements from 1975 to 1978 give annual accumulation values at $M G A$ of $0.75 \mathrm{~m}$ of snow and at $E 065$ of $0.32 \mathrm{~m}$ of snow. Cane-farm measurements from 1983 to 1992 at LGBO0 give an annual accumulation of $0.34 \mathrm{~m}$ of snow. 7 years of cane-farm accumulation at LGBOO ihus corresponds to four apparent $\delta^{18} \mathrm{O}$ cycles.

\section{RECENT TEMPORAL VARIABILITY}

To determine temporal records of accumulation rate over recent decades, three shallow firn cores were drilled within $50 \mathrm{~km}$ of each other approximately along $68^{\circ} 39^{\prime} \mathrm{S}$ at sites designated LGB00, MGA and E065 (Fig. 1). The sites were selected because they represented the highest known accumulation rates in the $1800-2000 \mathrm{~m}$ elevation range in eastern Kemp Land, and depth hoar was not developed at these sites. The accumulation rates measured on cancs at each of the sites are 153 (9year epoch 1983-92), 270 (3 year epoch 1975-78) and $135 \mathrm{~kg} \mathrm{~m}^{-2} \mathrm{a}^{-1}$ (3 year epoch 1975-78), respectively. Each of the cores was analysed for visible-layer stratigraphy, oxygen isotope $\left(\delta^{18} \mathrm{O}\right)$ and electrical conductivity. The techniques used were identical to those successfully employed on cores with average accumulation rates of $300-320 \mathrm{~kg} \mathrm{~m}^{-2} \mathrm{a}^{-1}$ in Wilkes Land at the same elevation (Goodwin, 1991). The standard model of firn stratigraphy interprets the annual autumn wind-glazed ice crust overlying less-dense firn and a summer radiation-glazed surface as the annual horizon marker (Goodwin, 1991). The autumn wind-glaze ice crust is $0.001-0.005 \mathrm{~m}$ thick, opaque and multi-layered, and distinct from the summer radiation glaze, which is less than $0.001 \mathrm{~m}$ thick and transparent. Generally, the peak $\delta^{18} \mathrm{O}$ signal occurs in snow located above the radiation glaze, whilst the peak conductivity signal occurs in the late summer to carly autumn snow, often in association with the autumn wind-glazed ice crust. To account for the relatively low accumulation rates at
LGB00 and E065, the core sampling was conducted using a sampling interval of $3-5 \mathrm{~cm}$ or a minimum of eight-ten samples a year.

The $\delta^{18} \mathrm{O}$ profiles for the three cores are shown in Figure 4. All three cores show variations in the $\delta^{18} \mathrm{O}$ signal that in part seem cyclic. The cyclicity is attributed to the seasonal variation in the $\delta^{18} \mathrm{O}$ of precipitation (nominally $8-10 \%$ ), but a significant proportion of cycles have an amplitude less than the seasonal variation (e.g. 10.5-12.5 $\mathrm{m}$ depth in MGA, $915 \mathrm{~m}$ depth in LGB00 and 2-4 $\mathrm{m}$ depth in E065). 'The reduced signal amplitude is often due to a lack of isotopically heavier peak summer snowfall (less negative $\delta^{18} \mathrm{O}$ values) and to a lesser extent the winter peak values. This would occur if the bulk of the accumulated snow for those years fell during autumn and spring.

Analysis of the $\delta^{18} \mathrm{O}$ profiles shows that the wavelength of the cycles corresponds to accumulation rates greater than those measured on the canes. For example, at LGB00 7 years of cane accumulation corresponds to only four $\delta^{18} \mathrm{O}$ cycles. Consequently, the observed $\delta^{18} \mathrm{O}$ cycles cannot be interpreted as representative of annual accumulation rates. Rather, it is likely that the $\delta^{18} \mathrm{O}$ cycles represent the effect of surface-redistribution processes in modifying the accumulation of precipitated and wind-transported snow at a site. At LGBO0 and E065, the surface roughness or micro-relief due to snow dunes and sastrugi is approximately equivalent to or greater than 1 year's snow accumulation ( $0.3 \mathrm{~m}$ snow). This region experiences strong katabatic winds and the mean winter wind speed measured at an automatic 
weather station at LGB00 is in excess of $12 \mathrm{~m} \mathrm{~s}^{-1}$ (Allison and others, 1993). Under these conditions, snow is primarily redistributed downwind by saltation and as mobile snow dunes. Strong wind crusts develop over the surface of snow dunes under high winds, which allow their form to be partly preserved in the snowpack. Whilst the $\delta^{18} \mathrm{O}$ cycles in the three firn cores resemble seasonal precipitation cycles, it is more appropriate to interpret them as a sample through a mixture of seasonal snow surfaces and stacked snow dunes, i.c. the core intersects a succession of dune morphologies and thicknesses rather than a succession of annual layers. Consequently, the $\delta^{18} \mathrm{O}$ cycles represent the stratigraphy and size of the dunc which may be maintained above the height of the -surrounding snow surface for more than one balance year.

The MGA $\delta^{13} \mathrm{O}$ profile shows the most consistent cyclicity of the threc cores, indicating that the bulk of precipitation remains in situ rather than being redistributed downwind at this sitc. However, as is evident in Figure 4 from scctions of relative homogeneity in the $\delta^{18} \mathrm{O}$ values, there are a number of sections in all the stratigraphic profiles where there appears to be a break or long-term hiatus in the continuous accumulation record. This is supported by a relatively homogencous conductivity signal and absence of ice crusts and layers. Such homogeneous signals would result from the deposition of a snow dune greatcr in height than at least 1 ycar's average accumulation. Thus, accumulation at a site in Kemp Land is likely to be constructed from partial in-situ accumulation of precipitation and to a greater extent from dunes or dune remnants formed from redistributed snow. Accumulation time series could not be derived for the LGBOO and E065 sites, and an accumulation time serics from the higher accumulation site at MGA requires independent verification using an absolute-dating horizon (for example, the 1955 or 1965 bomb-radioactivity horizons) to resolve the remaining ambiguitics in the core.

\section{CONCLUSIONS}

The spatial accumulation pattern in eastern Kemp Iand in the elevation range $1850-2700 \mathrm{~m}$ is significantly lower than that for the same elevation range in much of East Antarctica. Whilst little is known of the controlling synoptic mechanisms for this precipitation regime, it is apparent that the accumulation at a point is largely a function of the surface-snow redistribution processes and the divergent surface-wind ficld throughout the western Lambcrt Glacier basin. The combined stratigraphic investigations of shallow firn cores from relatively lowaccumulation areas in a strong katabatic wind zone indicates that it is incorrect to interpret $\delta^{18} \mathrm{O}$ cycles as seasonal cycles and to deducc annual accumulation time series from these rccords. Whilst these stratigraphic methods have been proven to be accurate in highaccumulation areas such as Wilkes Land, where the accumulation rate is $300 \mathrm{kgm}^{2} \mathrm{a}^{1}$ or greater, it is apparent from this study that areas with lower accum- ulation rates are unsuitable for $\delta^{18} \mathrm{O}$ stratigraphy. Consequently, it is imperative to have an independent measure of the annual accumulation rate, from either long-term cane measurements or from absolute datable horizons if $\delta^{18} \mathrm{O}$ stratigraphy is to be applied to the determination of accumulation-rate time series in lowaccumulation areas, which cover much of the interior of East Antarctica.

\section{ACKNOWLEDGEMENTS}

This project was in part funded by a 1992-93 ASAC grant to I. Goodwin and a grant from the Australian Antarctic Foundation to I. Allison for Ren Jiawern's participation. We acknowledge the assistance of all the members of the 199091 and 1992-93 LARGE traverse parties and of Mawson Station personnel with preparation and support for the traverses. N. Young and $R$. Massom contributed useful discussion regarding the microwave data.

\section{REFERENCES}

Allisur, I., G. Wendler and U. Radok. 1993. Climatology of the East Antarctic ice sheet $\left(100^{\circ} \mathrm{E}\right.$ to $\left.140^{\circ} \mathrm{E}\right)$ derived from automatic weather stations. 7. Geophrs. Res., 98 105, 8815-8823.

Bromwich, D. H. 1988. Snoufall in high southern lititudes. Fei. Geophss.. 26 $(1 ;, 149-168$

Drewry. D.J. 1983. The surface of the Antarctic ice sheet. In Drewry, D.J. ed. Antartica: glaciological and genphysical folio. Cambridge. University of Cambridge. Scott Polar Research Institute, sheet 2.

Drewry, D.J. and E. M. Morris. 1992. The response of large ice sheets to climatic change. Phit. Trans. R. Soc. Lond. B338, 235-242.

Fily, M. and J.-P. Benoist. 1991. Large-srale statistical study of Scanning Multichanncl Microwave Radiometer SMMIR) data over Antarctica. 7. Glaciol., 37 125), 129-139.

Giovinetto, M. B. and C. Bull. 1987. Summon and analyses of surface mass balance compilations for Antartica, 1960-1985, Byrd Polar Res. Cent.. Ohio State Univ, Columbus. (Report 1.)

Giovinetto, M. B., D. I1. Bromwich and G. Wendler. 1992. Atmospheric net transport of water vapor and latent heat across $70^{\circ} \mathrm{S}$. J. Goppless. Res., 97 D 1), 917-930.

Goodwin, I. D. 1990. Snow accumulation and surface topography in the katabatic zone of castern Wilkes land. Antart. Sri., 2 3), 235-242.

Goodwin, I. D. 1991. Snow-accumulation variability from seasonal surface observations and firn-core stratigraphy, eastern Wilkes Land, Antarctica. 7. Glaciol., 37(127;, 383-387.

Morgan, V.J. and T.H. Jacka. 1979. Mass balance studies in tast Antarctica. In Allison, I. ed. Sea Lecel, Ice and Climatic Change. Intemational Association of IJdrological Scinces Publication, 131, 253260.

Remy, F. and J. r. Minster. 1991. A comparison between active and passive microwave measurements of the Antarctic ice sheet and their association with the surface katabatic winds. 7. Glaciol., 37 125 . $3-10$.

Rotman, S. R., A.D. Fisher and D.H. Staelin. 1982. Inversion for physical characteristics of snow using passive radiometric abservations. 7. Glaciol., 28 (98), 179-185.

Shuman, C. A., R.B. Alley and S. Anandakrishnan. 1993. Characterization of a hoar-development episode using SSAI/I brightness temperatures in the vicinity of the GISP2 site, Greenland. Ann. Glaciol., 17, 183-188.

Zwally, H.J. 1977. Microware emissivity and accumulation rate of polar firn. 7. Glaciol, 18 (79), 195 215.

The accuracy of references in the text and in this list is the responsibility of the authors, to whom queries should be addressed. 